\title{
Palaeozoic metallogeny in Tethyan Black Mountain Basin, Bhutan Himalaya and its regional implication
}

\author{
Anupendu Gupta \\ Ex Geological Survey Of India, BB 45/3, Salt Lake, Kolkata 700064, INDIA
}

For correspondence, E-mail: anupendu@yahoo.com

Several isolated domains of Tethyan Palaeozoic sediments occur within the central crystalline complex of Bhutan Himalaya.The Black Mountain Group in central Bhutan represents one such sediment dominated ensemble of Tethyan affinity,which occupies about $6000 \mathrm{sq} \mathrm{km}$ area and rests unconformably on the Precambrian basement (Figure 1, inset). On the basis of fossil finds the age range of the sequence is considered to be Lower Ordovician to Devonian (Chaturvedi et al 1983 a, b ).The sequence begins with Early Ordovician cross bedded orthoquartzite and polimictic conglomerate of Nake Chu Formation and represents a proximal facies deposit in shallow water shelf condition. This is followed upwards by the thick interbanded sequence of Middle to Upper Ordovician Mane Ting Formation comprising quartz wacke and rudites (debri flow deposit), psammopelites, carbon phyllite (black shale), minor metavolcanics of andesitic composition, and stratabound manganoan siderite bands hosting copper sulphide mineralisation. The uppermost Wachila Formation, composed dominantly of carbonate lithofacies was deposited in a deep water setting during Silurian and most of Devonian period.

The sediments of Mane Ting Formation, which host the copper deposit at Gongkhola - Nobji Chu reflects intermittent basinal instability caused by tectno- magmatic impulses as depicted by the development of debri flow units at various stratigraphic levels and minor volcanics (Bandyopadhyay and Gupta 1990). In contrast to this there were periods of quiescence marked by deposition of thinly laminated black shale. The formational strike of lithounits in the deposit is NE-SW with average dip of $55-65^{\circ}$ towards NW and the ore bodies show overall conformity with this attitude.

The rocks of the area display a low grade of metamorphism and at least two deformative episodes. The earliest fold deformation is most widely recorded in the pelites and psammopelites as mesoscopic inclined to reclined folds on bedding with strong development of axial plane schistosity.

The siderite hosted ore bodies are best developed along the interface of contrasting lithounits, carbon phyllite (black shale) in the hangwall and lithic wacke (often rudaceous) in the footwall, and display conformable disposition with respect to the country rock. Several ore zones with varying persistence, width and sulphide concentration have been located along different tectono-stratigraphic levels. The most prominent ore body occurs along the southern contact of the main carbon phyllite horizon, extending for more then $5 \mathrm{~km}$ with local breaks (Figure 1).The average width of the main ore body is about 10 $\mathrm{m}$, the subsidiery mineralised bands measure upto 1 to $3 \mathrm{~m}$. The principal sulphide assemblege in association with sideritic rock is composed of chalcopyrite, pyrrhotite, pyrite, arsenopyrite, galena and sphalerite. Chalcopyrite or pyrrhotite mostly dominates other sulphides. All the sulphide phases are seen to coexist showing mutual boundary relationship, mutual embayment and mutual inclusion. Pyrrhotite displays significant poligonisation with the development of straight boundary and triple point. Twining is also evident in both pyrrhotite and chalcopyrite. The textural features in general indicate static recrystallization of the sulphides.

Besides the mostly chalcopyrite dominant sulphide assemblage in siderite host, very fine dissemination and streaks of pyrite and pyrrhotite parallel to the thin bedding laminates are noted in the carbonaceous phyllite. This bedding- controlled mineralization evidently represents the common syngenetic/ diagenetic phase of sulphide mineralization. Another conspicuous mode of mineralization, as noted in the calcareous wacke and quartzite, is depicted by pyrrhotite streaks and blebs strongly oriented parallel to the dominant schistosity, displaying sulphide schistosity at places.

While considering the genetic aspects of the deposit it may be seen that there are multiple phases of sulphide mineralization in the area, viz. (a) syngenetic sedimentary/diagenetic iron sulphide in black shale, (b)pre-metamorphic (possibly diagenetic) iron sulphide in wacke, and (c) copper sulphide within or in close association with manganoan siderite. It is evident that siderite provides the basic control on the localisation of the principal phase of copper sulphide mineralization in this deposit and the ore mineral emplacement is broadly coeval or marginally post-dates the formation of coarsely crystalline siderite gangue. While looking into the possible processes leading to the formation of siderite gangue, in order to understand the genesis of associated main sulphide phase, it is observed that viable genetic processes are: (a) direct sedimentary deposition followed by remobilization, (b) diagenetic segregation along favourable strata followed by remobilization, (c) hydrothermal epigenetic emplacement in tectono metamorphic stage. The other theoritical possibility of sideritic rock being a carbonatitic intrusion may be discarded in view of unfavourable tectonic set up, absence of characteristic petrological suite and mineral indicators, and low abundance of $\mathrm{Zr}, \mathrm{Nb}$ and $\mathrm{Sr}$. There is no direct evidence in form of internal sedimentary structures to support the concept of purely sedimentary origin of the siderite bed. However, close proximity of the debri flow deposits and volcanic components with sulphidic siderite does indicate an unstable basinal condition which could trigger sudden physico-chemical changes to cause deposition of iron carbonate aided by metallic additives from volcanic exhalative source, following the major destabilising impulses in an unstable slope succession. Another equally tenable genetic process could be diagenetic segregation of crystalline sideriti rock along energised litho contacts and other similar surfaces, giving rise to more or less stratabound disposition. The process of recrystallization and remobilization could continue up to early tectonic stage, thereby resulting in local discordant and transgressive features. The same diageneticepigenetic process could be responsible for the emplacement of silica and sulphides within the carbonate host. This may be followed by processes of reconstitution and remobilization over a protracted time span from late diagenetic to early tectonometamorphic stage. The entire process could be governed by a low to moderate temperature hydrodynamic system, the ore 


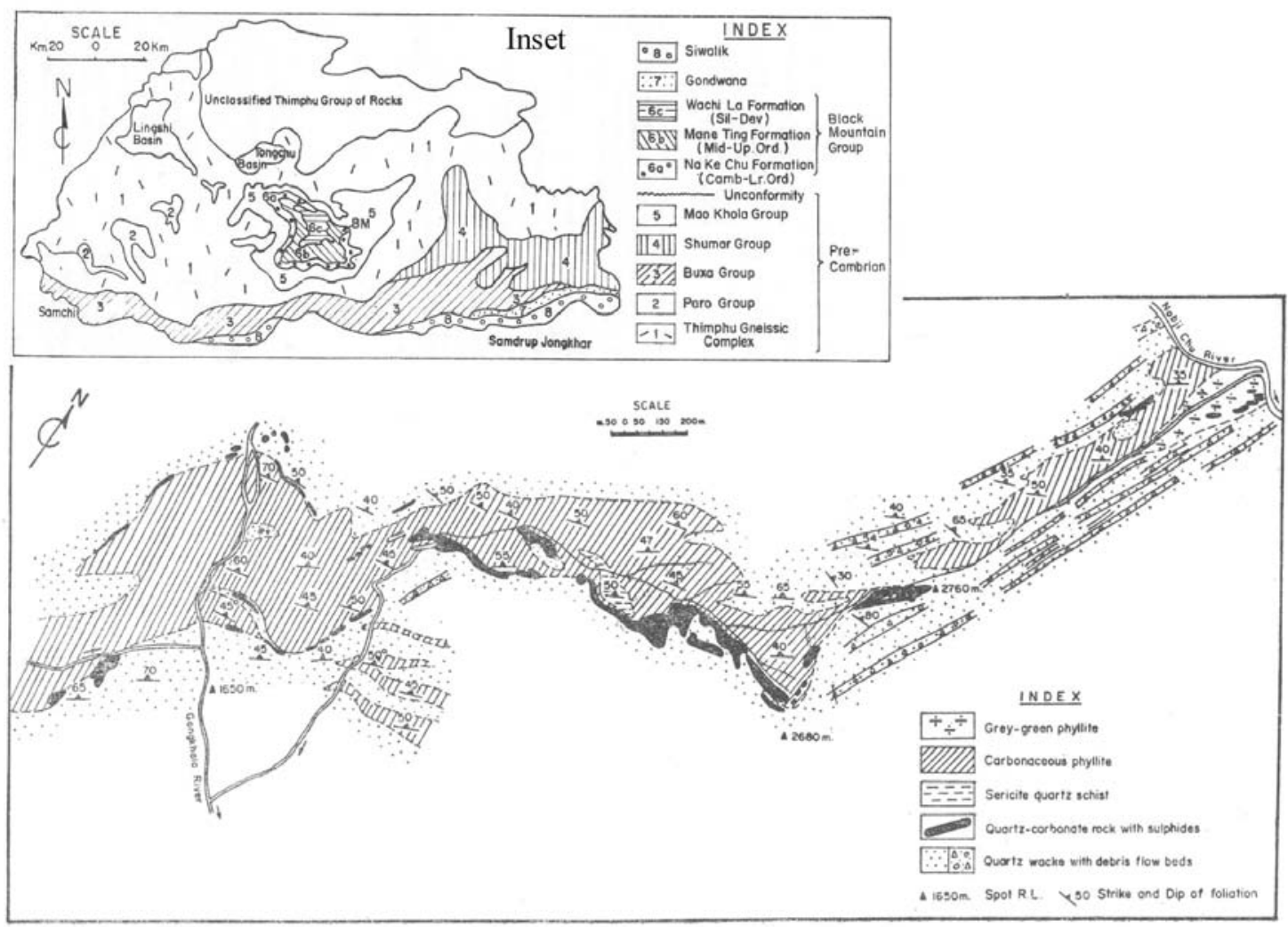

FIGURE 1. Geological map of Gongkhola-Nobji Chu area, Tongsa district, Bhutan. Inset: Simplifiedgeological map of Bhutan showing location of Black Mountain Basin (BM)

forming fluids and nutrients derived from sediments themselves and thermal component derived from deformative processes. However, the possible role of an hydrodynamic system set up by exhalative source may also be considered in this model in conjunction with diagenetic recrystallization. The concept of entirely external source for copper sulphides in both the above models is to a great extent weakened by the fact that the volcanic components themselves do not show any significant metal concentration and these are far insignificant in proportion compared to the siderite hosted sulphide body. As such, a combination of sedimentary and diagenetic processes for the initial deposition of carbonate followed by its recrystallization, local segregation along favoured domains, emplacement of silica and copper sulphides by a diagenetic/epigenetic hydrodynamic system and some amount of later remobilization during tectonometamorphic stage may, thus, be regarded as the most viable ore genetic model for the deposit (Gupta and Bandyopadhyay 2000).

The copper deposit at Gongkhola, though of limited economic potentiality (about $2.5 \mathrm{mt}$ ore reserve with $1.56 \% \mathrm{cu}$ ), is by far the best located in the Himalaya. The unique geological setting of the deposit and the mode of mineralization may, however, provide definite clue for similar occurrences elsewhere in the Himalayan belt. The fossiliferous Palaeozoic sequences of Tethyan affinity are recognised in many parts of this belt, which should be regarded as first order potential milieu, followed by search and identification of the suitable sedimentary packages, possible signatures of basin instability during sedimentation due to tectono-magmatic impulses and evidences of low to moderate temperature diagenetic/epithermal hydrodynamic activity. In the northeastern parts of Bhutan, Palaeozoic sequences similar to the Black Mountain Group were located which extends more prominently into the northwestern territory of Arunachal Pradesh, India. It is felt that the regional implication of the deposiit at Gongkhola would deserve due attention and serious follow-up.

\section{References}

Bandyopadhyay BKand A Gupta.1990. Submarine debri-flow deposits from Ordovician Mane Ting Formation in Tethyan Black Mountain Basin, Central Bhutan. Ind J Geol 36: 277-289

Chaturvedi RK, SN Mishra andVV Mulay. 1983a. On fossiliferous Ordovician rocks of Black Mountain region, Bhutan Himalaya and their significance in stratigraphic correlation. Rec Geol Surv India 113 (2): 35-47

Chaturvedi RK, SN Mishra andVV Mulay. 1983b. On the Tethyan Palaeozoic sequence of Black Mountain region, Central Bhutan. Him Geol 11:224249

Gupta A and BK Bandyopadhyay. 2000. Siderite hosted copper sulphide mineralization in Palaeozoic sequence of east Himalaya, Bhutan. Abstract vol, IGC-2000 